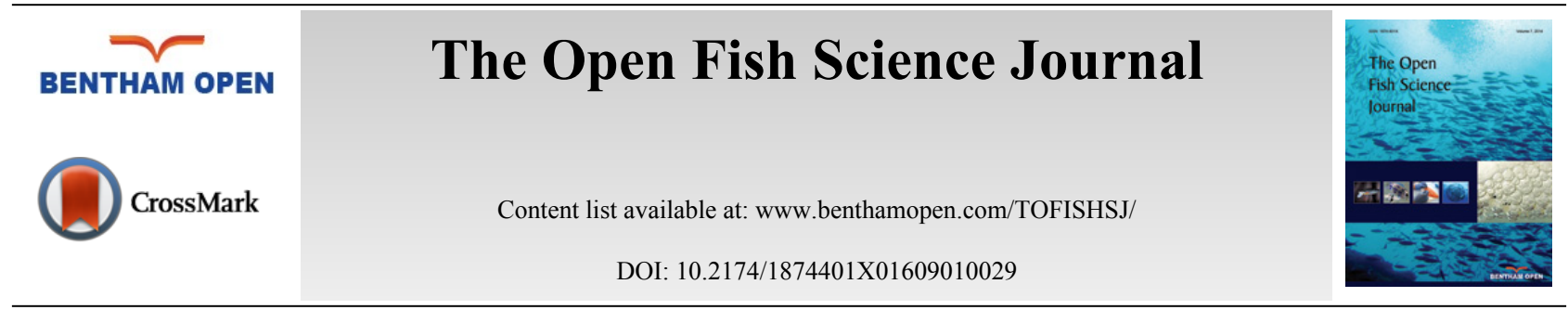

RESEARCH ARTICLE

\title{
Building a Better June Sucker: Characterization of Mouth Shape in the Captive Brood Stock
}

\author{
Mark C. Belk ${ }^{1, *}$, Madison Maxwell ${ }^{1}$, Clint Laidlaw $^{1}$ and Jeff Wesner ${ }^{2}$

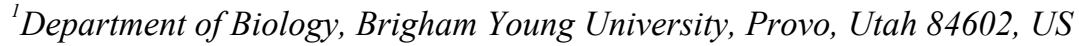 \\ ${ }^{2}$ Department of Biology, University of South Dakota, Vermillion, South Dakota 57069, US
}

Received: December 02, 2015

Revised: May 05, 2016

Accepted: May 09, 2016

\begin{abstract}
June sucker, Chasmistes liorus, is an endangered lake sucker endemic to Utah Lake, Utah, USA. Over the last two decades, captive-raised June suckers have been stocked into Utah Lake to augment the wild population. However, it has become apparent that the fish stocked from captive stock may not always represent the typical June sucker morphology. To determine the utility of current captive brood lots to produce June sucker phenotypes, we characterized shape of the lip lobes on the lower jaw of each brood lot. We obtained offspring from within-lot crosses and characterized shape of the lower lips using geometric morphometrics. We compared shape of brood lots to reference samples of June sucker and reference samples of the co-occurring sister species, Utah sucker (Catostomus ardens). Mean shape of the lower lips among brood lots varies from typical June sucker morphology to shapes typical of Utah sucker. Three brood lots had mean shape scores somewhat similar to the reference June sucker mean, and five brood lots had mean shape scores more similar to the reference Utah sucker mean. All other brood lots were intermediate representing hybrid phenotypes. Utilization of all brood lots on a roughly equal basis for augmentation in Utah Lake will likely result in the loss of typical June sucker morphology in the lake within a few decades. We recommend use of brood lots that exhibit June sucker morphology and discontinuance of use of brood lots that represent Utah sucker morphology. In addition, selection on lower lip shape in captive brood lots may be required to recreate June sucker phenotypes from captive brood stock.
\end{abstract}

Keywords: Chasmistes liorus, Endangered species recovery, Genetic and phenotypic diversity, Geometric morphometrics, Morphology.

\section{INTRODUCTION}

June sucker, Chasmistes liorus, is endemic to Utah Lake, Utah, USA, and is one of only four extant lake suckers in North America [1]. June sucker numbers declined during the mid-1900s and they were recognized as an endangered species in 1986 [2] with populations at one point estimated to be less than 1,000 total individuals and about 300 of reproductive age [3]. As a precautionary action, captive brood lots were created from forced spawning of wild June suckers captured from 1989 to 2003. Brood-lots were generated from wild-caught individuals with the goal of producing 20, genetically independent brood lots that would represent the genetic diversity of the wild population. The brood lots represent a refuge for the species and are to be used to produce fish to augment the wild population. Captiveraised June sucker have been transferred to the lake on a nearly annual basis beginning in the early 1990's [4, 5]. Over the last two decades several hundred thousand offspring generated from captive brood lots have been stocked back into Utah Lake to augment the wild-produced population. The majority of June sucker in Utah Lake currently are from these stocking events. However, it has become apparent that the fish stocked from brood lots may not always represent the typical June sucker morphology based on morphological description and characterization of the wild population [1, 6; see description below].

\footnotetext{
* Address correspondence to this author at Department of Biology, Brigham Young University, Provo, Utah 84602, US; Tel: 801-422-4154; E-mail: mark_belk@byu.edu
} 
Utah Lake also contains an additional morphologically distinct species of sucker, Utah sucker (Catostomus ardens). June sucker are characterized by a wide mouth, thin and widely separated lower lip lobes, and few papillae on the lower lips, whereas, Utah sucker have smaller mouths, broad lower lip lobes that have no gap between them, and highly papillose lip lobes $[1,6]$. Hybridization is known to occur between the two species and loss of distinct June sucker morphology is considered a significant threat to June sucker [3]. There is clear neutral genetic evidence that Utah sucker from the Bonneville basin (located in the northern half of Utah, USA) are deeply diverged from Utah sucker in the Snake River drainage (located directly to the north of the Bonneville basin in southern Idaho and western Wyoming, USA). In contrast, the neutral genetic markers show no evidence of divergence between Utah suckers and June suckers in Utah Lake [7]. However, divergence of neutral traits may lag behind other indicators of divergence such as that from ecological or functional traits and may be further obscured by reticulate patterns of evolution or hybridization between species. Rapid morphological and ecological divergence has been observed in species where neutral genetic markers would indicate little divergence (e.g. sticklebacks [8], African cichlids [9, 10], whitefish [11]). When levels of gene flow among groups are low, neutral molecular genetic markers will diverge at a relatively constant rate regardless of the selective environments in which the populations are found. However, the selective environment may drive comparably rapid divergence in ecological or functional traits under strong selection [12].

Though functional traits may evolve relatively quickly and drive considerable phenotypic change they may be driven by the change of only a small portion of the genes present in an organism and may thus be difficult to detect even with current genome-wide survey methods. In contrast to the lack of differences in neutral genetic markers between June sucker and Utah sucker, mouth morphology (specifically the shape and separation of the lower lip lobes) has been shown to represent a genetically based, functional trait that has a moderate level of heritability (i.e., 0.27) [13].

Creating and obtaining sufficient brood lots was a high priority in the 1990's and early 2000's because of the dwindling number of wild individuals that represented the classic June sucker morphology. To create brood lots, personnel from the Utah Division of Wildlife Resources captured and selected representative June suckers during the spawn and stimulated spawning streamside. Early lots were generated using 1-3 females and 1-3 males, whereas subsequent lots were generated using a single male and a single female. Fertilized eggs were transported to the Fisheries Experiment Station where they were hatched and reared up to a size suitable for reintroduction to the lake. A sustainable number were maintained in the hatchery to perpetuate the brood lot. Each brood lot was maintained separately from all other brood lots.

Although this process produced the desired number of brood lots, ensuring that each brood lot represents classic June sucker morphology is difficult. When brood lots were generated care was taken to insure that the individuals used displayed the best June Sucker phenotype available. The low population size of reproductive June suckers in Utah Lake at the time of collection, and the limited time that any individual could be detained, constrained the availability of individuals with representative morphologies. Thus, it is likely that some brood lots, while generated with the most June-sucker-like individuals available at the time, may not reflect the historic June sucker morphology. To determine the utility of these brood lots to propagate June sucker phenotypes in Utah Lake it is important to characterize the phenotypes produced by each brood lot in relation to the range of variation in lower lip morphology displayed by June sucker and Utah sucker.

For brood lots to be useful in maintaining the integrity of June sucker they must represent the heritable variation that is characteristic of the species. To test the integrity of brood lots we characterized shape of the lower lips of individuals from each brood lot and compare these mean shapes among brood lots and to reference samples of June sucker and Utah sucker. We show that mean shape of the lower lips in captive brood lots of June sucker ranges from that typical of June sucker to that typical of Utah sucker, but most brood lots represent intermediate, hybrid phenotypes.

\section{MATERIALS AND METHODS}

To characterize the morphology generated by each brood lot we obtained offspring from within-lot crosses. Withinlot crosses were generated by personnel from Fisheries Experiment Station (FES; Logan, Utah, USA) using partial spawn output of females and males from each of the 23 extant brood lots. Fertilized eggs from the within-lot crosses were then hatched and maintained at FES until they reached the postflexion mesolarval stage of development [14]. Upon reaching the postflexion mesolarval stage they were transferred to cages in Utah Lake and maintained until late summer in the natural environment. It was preferable that the larvae experience the transition from the larval stage to the juvenile stage in the natural environment of Utah Lake because there are documented environmental effects on mouth morphology of June sucker [15]. Cages measured 1x1x0.5 meters, covered on five sides with screen mesh and 
covered on top with a larger mesh netting to deter predators. Fish were housed at densities of 25 individuals per cage, and we used multiple replicate cages for each brood lot to guard against lost cages or individual cage effects.

To accommodate the opportunity to create within-lot crosses of brood lots, we raised offspring from some brood lots in 2010, 2011, and 2013. All within-lot crosses were raised in the lake environment with the following exceptions. In 2010 the Camp Creek fish in cages in Utah Lake experienced poor survival (only three individuals survived), so additional hatchery-raised individuals were used in the analysis. Additionally, in 2013 low water levels in the lake led to catastrophic loss of almost all individuals in the cages in the lake, so hatchery-raised individuals had to be used for the analysis for brood lots 94LOT4, 94LOT11, and 94LOT6.

At the end of the growing season all individuals were removed, euthanized by overdose of MS-222 and preserved in formalin. They were then transported back to the lab, measured for standard length and mass and the ventral view of the mouth was photographed under a dissection microscope. The head of specimens was elevated such that the plane of the mouth was perpendicular to the view angle of the camera to provide a clear representation of the shape of the lower lips. Individuals that were deformed or misshapen because of preservation were removed from the analysis. A total of 541 specimens representing 23 brood lots were included in the final analysis (mean sample size per brood lot was 23.5; range 3 - 49; Table 1). Nine landmarks that characterized shape of the lower lip lobes and the gap between lips were then located on the images using TpsDig2 (F.J. Rohlf http://life.bio.sunysb.edu/morph/; (Fig. 1). Because lips are symmetrical structures we only fully characterized shape on the left lip lobe, but we included landmark 2 to provide a measure of the gap between lower lip lobes. Landmarks were placed as follows: 1) midline of anterior extent of lower jaw; 2) medial extent of right lower lip lobe; 3) medial extent of left lower lip lobe; 4) medial margin of left lower lip lobe about one-third of the way from landmark 3 to landmark $6 ; 5)$ medial margin of left lower lip lobe about two-thirds of the way from landmark 3 to landmark 6;6) posterior margin of left lower lip lobe; 7) posterior extent of left side of mouth; 8) anterior margin of left lower jaw about one-third of the way from landmark 7 to landmark 1;9) anterior margin of left lower jaw about two-thirds of the way from landmark 7 to landmark 1. Landmarks 2-5, 8, and 9 were considered sliding semi-landmarks and were slid using the minimize $d^{2}$ method in TpsRelW (F.J. Rohlf http://ife.bio.sunysb.edu/morph/). To generate shape variables, specimens were first aligned using a generalized orthogonal least-squares approach [16]. After alignment, 12 partial warps and 2 uniform components were calculated for each specimen yielding the weight matrix (W). Fourteen relative warps (RWs) were generated from a principal components analysis of the weight matrix (TpsRelW, F.J. Rohlf http://life.bio.sunysb.edu/morph/). However, sliding semi-landmarks provide only one degree of freedom, so the six smallest relative warps do not represent real variation. We evaluated the first eight relative warps to characterize overall shape variation.

Table 1. Sample size and scores on RW1 and RW2 of brood lots and reference samples. Positive scores on RW1 and negative scores on RW2 represent more June sucker-like shapes of the lower lips.

\begin{tabular}{|c|c|c|c|}
\hline Lot ID & N & RW1 & RW2 \\
\hline 00PR01 & 22 & 0.0260 & -0.0230 \\
\hline 00PR05 & 37 & -0.0210 & -0.0066 \\
\hline 01PR01 & 19 & -0.0400 & -0.0060 \\
\hline 01PR02 & 24 & -0.0330 & 0.0040 \\
\hline 01PR03 & 16 & -0.0650 & -0.0240 \\
\hline 01PR04 & 32 & -0.0250 & -0.0130 \\
\hline 01PR06 & 17 & 0.0010 & -0.0260 \\
\hline 01PR07 & 16 & -0.0040 & 0.0630 \\
\hline 02PR03 & 11 & 0.0027 & -0.0530 \\
\hline 02PR04 & 28 & -0.0400 & 0.0018 \\
\hline 02PR06 & 49 & 0.0080 & -0.0180 \\
\hline 02PR07 & 35 & -0.0150 & -0.0200 \\
\hline 02PR08 & 44 & -0.0080 & 0.0570 \\
\hline 03PR21 & 28 & 0.0090 & 0.0220 \\
\hline 03PR22 & 6 & -0.0100 & 0.0390 \\
\hline 03PR25 & 16 & 0.0450 & -0.0160 \\
\hline 89/91USU & 33 & 0.0055 & 0.0290 \\
\hline 94LOT8 & 3 & 0.0300 & -0.0150 \\
\hline 94lot11 & 20 & 0.0088 & \\
\hline
\end{tabular}




(Table 1) contd.....
\begin{tabular}{|c|c|c|c|}
\hline Lot ID & N & RW1 & RW2 \\
\hline 94lot4 & 20 & -0.0300 & 0.0086 \\
\hline 94lot6 & 24 & 0.0240 & -0.0320 \\
\hline 95LOT4 & 28 & 0.0023 & -0.0340 \\
\hline Camp Creek & 13 & 0.0540 & -0.0270 \\
\hline Reference June sucker & 78 & 0.0830 & 0.0003 \\
\hline Reference Utah sucker & 107 & -0.0310 & 0.0490 \\
\hline
\end{tabular}

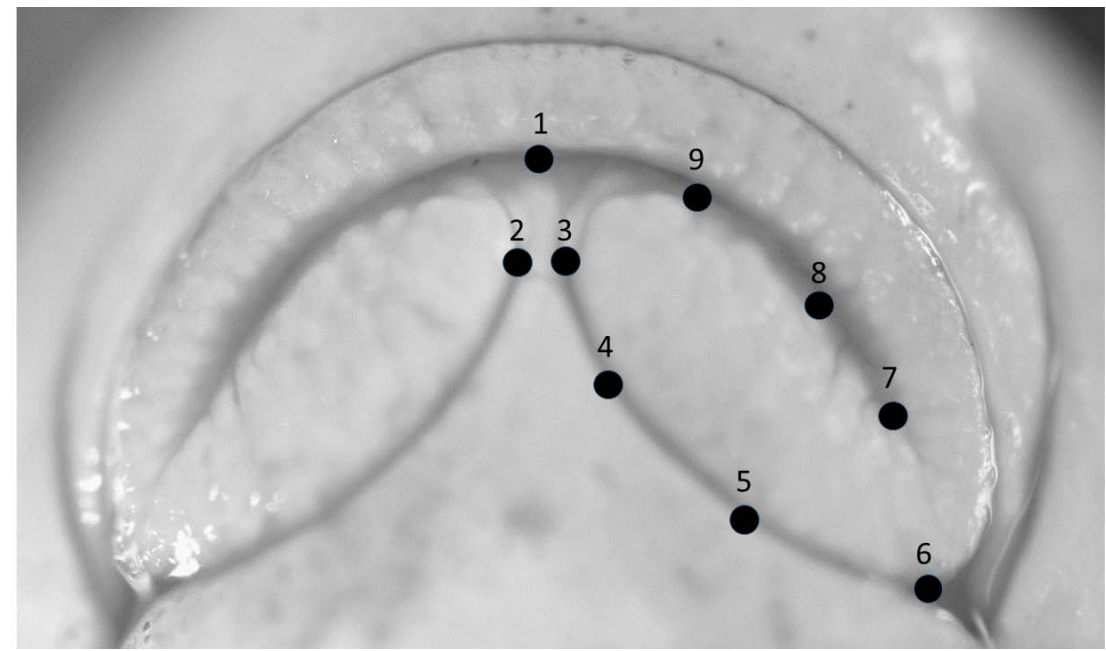

Fig. 1. Photograph of mouth of an individual sucker from this study with landmarks plotted.

To determine how shape of each brood lot compared to typical June sucker and Utah sucker morphology we added reference samples of June sucker and Utah sucker from a previous study on heritability of shape in these species [13]. Reference June suckers were obtained from crosses made from wild June sucker adults in Utah Lake ( $\mathrm{n}=78)$, and reference Utah suckers were obtained from crosses made from wild Utah sucker adults from Strawberry River located east of Utah Lake $(n=107)$. Shape of the lower lips was characterized using the same landmarks as for brood lots in the current study [13]. To characterize differences among brood lots and to determine how they aligned with reference groups, we plotted means and standard errors of the mean for each brood lot and for the reference June sucker and Utah sucker samples on the first two relative warps. In addition, we plotted an ellipse that represents \pm 1 standard deviation of the mean for the reference samples for both species. Relative warps 1 and 2 represent $57 \%$ of total shape variation and reference samples of June sucker and Utah sucker segregate toward the extremes on each of these axes. On the contrary, shape variation on relative warps 3-8 does not represent variation between the two species. Means for both species' reference samples fall near the middle of the axis on these relative warps and the reference samples are not significantly segregated. For this reason we confine our analysis to the first two relative warps. We characterize the shape variation associated with each relative warp by providing thin-plate spline deformations for the observed extremes of each axis using TpsRelW (F.J. Rohlf http://life.bio.sunysb.edu/morph/).

\section{RESULTS}

Mean shape of the lower lip lobes varies among brood lots from typical June sucker morphology to typical Utah sucker morphology. On RW1 typical June sucker morphology (narrow lips and wide gap) is represented by positive scores (Fig. 2A) and the June sucker reference samples fall to the extreme right on this axis (Table 1; Fig. 3). Similarly, typical Utah sucker morphology (wide lips and no gap) is represented by negative scores (Fig. 2B) and the Utah sucker reference samples fall to the extreme left on RW1 (Table 1; Fig. 3). On RW2 June sucker morphology is represented by negative scores (Fig. 2C), and reference samples fall near zero (Table 1; Fig. 3). Utah sucker morphology is represented by positive scores (Fig. 2D), and reference samples are located on the positive end of the axis (Table 1; Fig. 3). Thus, brood lots that represent typical June sucker morphology are found in the lower right quadrant of the plot of RW1 and RW2 and brood lots that represent Utah sucker morphology fall in the upper left quadrant (Fig. 3). 

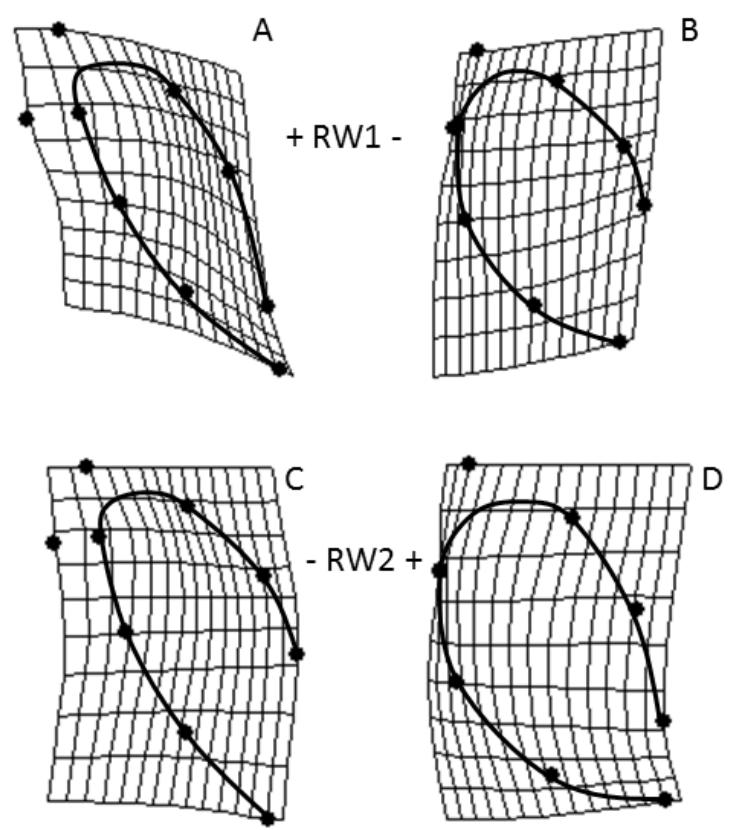

Fig. 2. Thin plate spline deformations of shape of lower lip representing positive and negative extremes observed among samples. A) Positive scores on RW1 represent June sucker-like shapes. B) Negative scores on RW1 represent Utah sucker-like shapes. C) Negative scores on RW2 represent June sucker-like shapes. D) Positive scores on RW2 represent Utah sucker-like shapes.

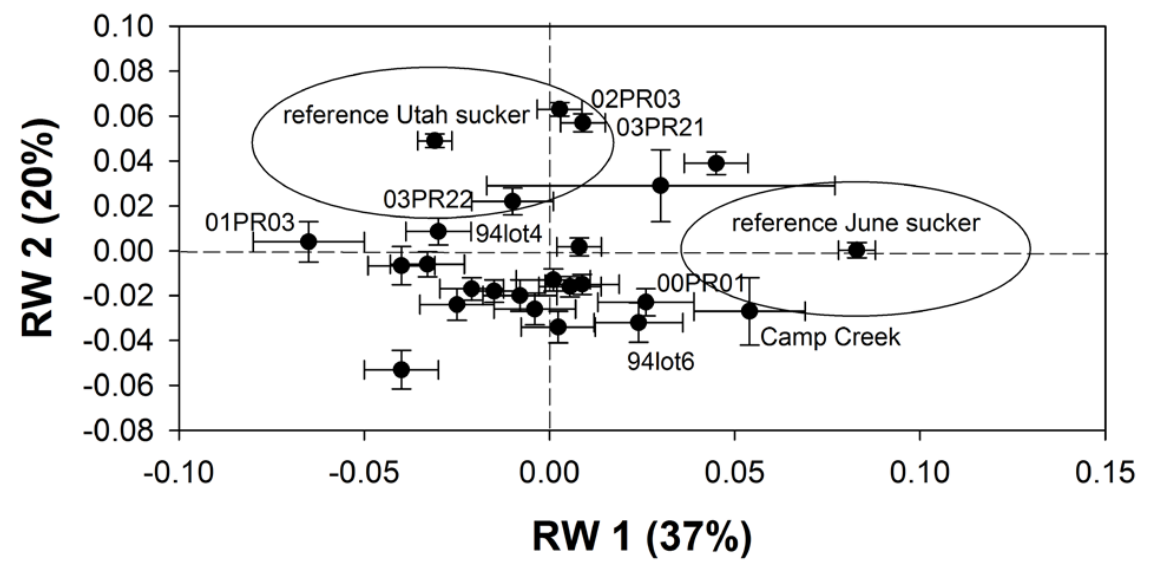

Fig. 3. Least-squares means ( $\pm 1 \mathrm{SE}$ ) for lower lip shape for each brood lot and for reference June sucker and reference Utah sucker samples on relative warps 1 and 2. Reference sample means and brood lot means most like reference samples in shape are labeled. Ellipses surrounding reference sample means represent \pm 1 standard deviation of the mean.

Means of shape of lower lips of brood lots on RW1 are mostly clustered between the extremes represented by the reference samples of June sucker and Utah sucker. None of the brood lots are as extreme as the June sucker reference samples, and only two brood lots have means that fall within one standard deviation of the mean of the June sucker reference sample. In contrast, all but 5 brood lots fall within one standard deviation of the Utah sucker reference sample on RW1 (Fig. 3). On RW2 most of the brood lots fall within one standard deviation of the reference sample of June sucker. Thus, most brood lots represent a hybrid morphology located between typical June sucker and typical Utah sucker phenotypes. The three brood lots that exhibit the most June sucker-like morphology of the lips are Camp Creek, 00PR01, and 94lot6. Five brood lots that exhibit the most Utah sucker-like morphology of the lower lips are 01PR03, 03PR21, 03PR22, 02PR03, and 94lot4 (Fig. 3). 


\section{DISCUSSION}

There is considerable variation in the lower lip shapes of the brood lots used to augment wild populations of June suckers in Utah Lake. This variation is partially heritable [13]. Lower lip shape is the most reliable trait available for discrimination between June sucker and Utah sucker [13]. Unlike the Modoc sucker, Catostomus microps, which was recently proposed for delisting because of "continued ecological and morphological integrity" [17], June sucker show high levels of hybridization with Utah sucker and consequent loss of morphological integrity. Thus, maintaining the typical June sucker morphology in Utah Lake is the most effective way to avoid loss of the species through hybridization in the future.

Utilization of all brood lots on a roughly equal basis for augmentation of the population in Utah Lake will likely result in the near complete loss of typical June sucker morphology in the lake within a few decades at most. The resulting population will reflect a hybrid morphology between June sucker and Utah sucker. Although the genetic variation that generates typical June sucker morphology will not likely be lost, the phenotypic variation typical of June sucker will no longer be observed. Selective use of brood lots or individuals within brood lots (i.e., artificial selection) for reproduction now will likely avoid the complete loss of June sucker phenotypes. However, selection of brood lots will need to be aggressive and fairly long-lasting (e.g., several decades) to maintain the distinct June sucker phenotype in Utah Lake. If current practices prevail and selection of brood lots based on phenotype is delayed, it would require stronger selection of brood stock and likely multiple generations of selective breeding to restore a typical June sucker morphology.

Natural selection over the course of many generations has produced the distinct morphologies of June sucker and Utah sucker in Utah Lake. It may be reasonable to expect that natural selection in Utah Lake might favor the distinct morphologies over a hybrid morphology. However, several lines of evidence suggest that the current environment in Utah Lake is unlikely to create selection for typical June sucker morphology. First, in fishes, distinct morphologies often evolve in response to availability of distinct habitats in deep lakes [18 - 20]. Benthic and pelagic forms are common in many species and systems. June sucker feed in the water column on suspended zooplankton; whereas, Utah sucker feed on the benthos on benthic macroinvertebrates. Similar benthic and pelagic forms have evolved in other western suckers (e.g., Chasmistes cujus, and Catostomus tahoensis in Nevada [21],). Utah Lake is a small remnant of the large and deep lake Bonneville that existed up until about 10,000 YBP. Lake Bonneville had distinct, and well separated benthic and pelagic habitats that would likely have created selective pressure for distinct morphologies between June sucker and Utah sucker. Currently, Utah Lake is a shallow lake (average depth is $3.2 \mathrm{~m}$ ) with little spatial differentiation between benthic and pelagic habitats. It seems unlikely that habitats available in a shallow lake would create sufficient selective pressures to maintain morphological differences between species. Second, a study on heritability of mouth morphology that included June sucker, Utah sucker, and hybrids found no difference in survival or growth of young-of-year fish between more pure June sucker, Utah sucker, and hybrids in Utah Lake [13]. Third, in the lake, hybrids are more common than either typical June sucker or typical Utah sucker even if we discount the fish that have been stocked from the captive breeding program [6].

It could be argued that a reduction in the number of brood lots used for captive propagation may create a genetic bottleneck. By eliminating genetic diversity, such a bottleneck would reduce the ability of June sucker to adapt to changing conditions in the lake and may affect fecundity or survival. However, a population bottleneck has already occurred in June sucker. Low populations of June suckers in the lake account for the difficulty of obtaining wild suckers showing a typical June sucker phenotype at the time that the brood lots were generated, despite the valiant efforts of those involved. Lack of genetic diversity may represent a threat to future evolutionary change in June sucker. However, genetic diversity that does not maintain the distinctive morphology of June sucker is of little use. Relatively few brood lots represent typical June sucker morphology, but producing a hybrid swarm in place of June sucker does not accomplish the goal of maintaining the species. If lack of genetic diversity becomes a problem in the future, it can be easily remedied with the introduction of Utah sucker or hybrids. We should not sacrifice June sucker morphology for the longer term goal of maintaining genetic diversity especially when part of that genetic diversity does not represent June sucker morphology.

We recommend exclusive use of brood lots and selection of individuals within brood lots that exhibit June sucker morphology. The difficulty with this position is determining where to draw the line. Clearly, the 3 lots that show the most typical June sucker morphology (Fig. 3) should be used for future propagation. Similarly, the 5 lots that show the most typical Utah sucker morphology (Fig. 3) should not be used. The question is what to do with the majority of the brood lots that represent hybrid morphologies. Intermediate lots could be aggressively selected such that their lower lip 
phenotype shifts more toward June sucker within a few generations. This is a long term proposition and it ignores the possibility that selection on shape of lower lips may not restore other June sucker traits. However, at this point, lip shape is the most distinctive difference we can identify between the two species that has a known heritable basis [13]. The overall question of how to proceed with augmentation of the June sucker population in Utah Lake can be resolved deliberately based on the data available, or we can continue with current efforts and risk losing the species to extinction through hybridization we have exacerbated.

\section{CONFLICT OF INTEREST}

The authors confirm that this article content has no conflict of interest.

\section{ACKNOWLEDGEMENTS}

Funding for this project was provided by the June Sucker Recovery Implementation Program through the Central Utah Water Conservancy District. Permits to conduct the research were provided by the Utah Division of Wildlife Resources (permit number 1COLL5950 to MCB). The Institutional Animal Care and Use Committee at Brigham Young University provided approval for research with live animals (protocol numbers 10-0304 and 13-0702). Numerous undergraduates helped with the field work and image analysis.

\section{REFERENCES}

[1] Miller RR, Smith GR. Distribution and evolution of Chasmistes (Pisces: Catostomidae) in western North America. Report No. 0P696US. US: University of Michigan 1981; pp. 1-46.

[2] US Fish and Wildlife Service. Endangered and threatened wildlife and plants; final rule determining the June sucker (Chasmistes liorus) to be an endangered species with critical habitat. Fed Regist 1986; 51: 10851-7.

[3] US Fish and Wildlife Service. June sucker (Chasmistes liorus) recovery plan. Denver, CO: US Fish and Wildlife Service 1999.

[4] Rasmussen JE, Belk MC, Peck SL. Endangered species augmentation: a case study of alternative rearing methods. Endanger Species Res 2009; 8: 225-32.

[http://dx.doi.org/10.3354/esr00219]

[5] Billman EJ, Tjarks BJ, Belk MC. Effect of predation and habitat quality on growth and reproduction of a stream fish. Ecol Freshwat Fish 2011; 20: 102-13. [http://dx.doi.org/10.1111/j.1600-0633.2010.00465.x]

[6] Cole DD, Mock KE, Cardall BL, Crowl TA. Morphological and genetic structuring in the Utah Lake sucker complex. Mol Ecol 2008; 17(24): 5189-204.

[http://dx.doi.org/10.1111/j.1365-294X.2008.03990.x] [PMID: 19067800]

[7] Mock KE, Evans RP, Crawford M, Cardall BL, Janecke SU, Miller MP. Rangewide molecular structuring in the Utah sucker (Catostomus ardens). Mol Ecol 2006; 15(8): 2223-38.

[http://dx.doi.org/10.1111/j.1365-294X.2006.02932.x] [PMID: 16780436]

[8] Kristjansson BK, Skulason S, Noakes DL. Morphological segregation of Icelandic threespine stickleback (Gasterosteus aculeatus L). Biol J Linn Soc Lond 2002; 17(2): 247-57. [http://dx.doi.org/10.1046/j.1095-8312.2002.00063.x]

[9] Danley PD, Markert JA, Arnegard ME, Kocher TD. Divergence with gene flow in the rock-dwelling cichlids of Lake Malawi. Evolution 2000; 54(5): 1725-37.

[http://dx.doi.org/10.1111/j.0014-3820.2000.tb00716.x] [PMID: 11108599]

[10] Clabaut C, Bunje PM, Salzburger W, Meyer A. Geometric morphometric analyses provide evidence for the adaptive character of the Tanganyikan cichlid fish radiations. Evolution 2007; 61(3): 560-78. [http://dx.doi.org/10.1111/j.1558-5646.2007.00045.x] [PMID: 17348920]

[11] Bernatchez L. Ecological theory of adaptive radiation: an empirical assessment from coregonine fishes (Salmoniformes). In: Hendry AP, Stearns SC, Eds. Evolution illuminated: salmon and their relatives. Oxford: Oxford Univ Press 2004; pp. 175-207.

[12] Reznick DN, Shaw FH, Rodd FH, Shaw RG. Evaluation of the rate of evolution in natural populations of guppies (Poecilia reticulata). Science 1997; 275(5308): 1934-7. [http://dx.doi.org/10.1126/science.275.5308.1934] [PMID: 9072971]

[13] Belk MC, Schaalje GB. Multivariate heritability of shape in June sucker (Chasmistes liorus) and Utah sucker (Catostomus ardens): shape as a functional trait for discriminating closely related species. Dev Genes Evol 2016; 226(3): 197-207. [http://dx.doi.org/10.1007/s00427-016-0547-2] [PMID: 27138282]

[14] Snyder DE, Muth RT. Description and identification of June, Utah, and mountain sucker larvae and early juveniles Contributions of the larval fish laboratory, Colorado State University No 87-2891. Salt Lake City, UT: Utah Division of Wildlife Resources 1988.

[15] Belk MC, Benson LJ, Rasmussen J, Peck SL. Hatchery-induced morphological variation in an endangered fish: a challenge for hatchery-based 
recovery efforts. Can J Fish Aquat Sci 2008; 65(3): 401-8.

[http://dx.doi.org/10.1139/f07-176]

[16] Rohlf FJ, Slice D. Methods for comparison of sets of landmarks. Syst Zool 1990; 39: 40-59. [http://dx.doi.org/10.2307/2992207]

[17] Endangered and threatened wildlife and plants: remove the Modoc sucker from the federal list of endangered and threatened wildlife. Fed Regist 2014; 79: 8656-67.

[18] Day T, Pritchard J, Schluter D. A comparison of 2 sticklebacks. Evolution 1994; 48: 1723-34. [http://dx.doi.org/10.2307/2410260]

[19] Robinson BW, Schluter D. Natural selection and the evolution of adaptive genetic variation in northern freshwater fishes. In: Adaptive Genetic Variation in the Wild. New York, USA: Oxford University Press 2000

[20] Thibert-Plante X, Hendry AP. Factors influencing progress toward sympatric speciation. J Evol Biol 2011; 24(10): 2186-96. [http://dx.doi.org/10.1111/j.1420-9101.2011.02348.x] [PMID: 21707817]

[21] Buth DG, Haglund TR, Minckley WL. Duplicate gene-expression and allozyme divergence diagnostic for Catostomus tahoensis and the endangered Chasmistes cujus in Pyramid Lake, Nevada. Copeia 1992; 4: 935-41. [http://dx.doi.org/10.2307/1446623]

(C) Belk et al.; Licensee Bentham Open.

This is an open access article licensed under the terms of the Creative Commons Attribution-Non-Commercial 4.0 International Public License (CC BY-NC 4.0) (https://creativecommons.org/licenses/by-nc/4.0/legalcode), which permits unrestricted, non-commercial use, distribution and reproduction in any medium, provided the work is properly cited. 